\title{
Molecular characterization of Anaplasma phagocytophilum infection in the cervids and feeding ticks from Lithuania
}

\author{
Jana Radzijevskaja ${ }^{1 *}$, \\ Justina Snegiriovaite் \\ Artūras Kibiša ${ }^{1}$, \\ Irma Ražanskè ${ }^{1}$, \\ Algimantas Paulauskas $^{1}$ \\ ${ }^{1}$ Vytautas Magnus University, \\ K. Donelaičio g. 58, \\ 44248 Kaunas, Lithuania
}

Anaplasma phagocytophilum is a bacterial pathogen, which is a major cause of zoonotic disease, anaplasmosis. The main vectors of A. phagocytophilum are ticks of the Ixodes ricinus complex. A. phagocytophilum has a broad geographic distribution and a high degree of biological and clinical diversity. Epidemiological studies in multiple countries have shown that the prevalence of $A$. phagocytophilum highly depends on the density of ticks and their potential hosts such as the cervids, which are one of the main sources of nutrition for Ixodes ticks. In Lithuania, the cervids are important game animals but their contribution as reservoirs for $A$. phagocytophilum remains unknown. The objectives of the study were to investigate the prevalence of A. phagocytophilum infections in the cervids and feeding ticks and to characterize the A. phagocytophilum strains obtained from the cervids and ticks based on sequence analysis of $m s p 4$ gene. A total of 187 ticks were collected from 44 cervids (roe deer, red deer, and moose) harvested by professional hunters during the hunting seasons of 2010-2013 and 2016-2017 in Lithuania. Blood and spleen samples were collected from 29 animals (27 roe deer and two red deer). A. phagocytophilum DNA was identified in ten $(37.04 \%)$ of the 27 roe deer. The overall prevalence of A. phagocytophilum in I. ricinus and D. reticulatus ticks was $39.3 \%(70 / 178)$ and $22.2 \%(2 / 9)$ respectively. The sequence analysis of the $m s p 4$ gene of $A$. phagocytophilum revealed nine different sequence types: five $m s p 4$ sequence types were detected in ticks and seven in roe deer.

Keywords: Anaplasma phagocytophilum, ticks, Ixodes ricinus, Dermacentor reticulatus, cervids

\footnotetext{
*Corresponding author. Email: jana.radzijevskaja@vdu.lt
} 


\section{INTRODUCTION}

Anaplasma phagocytophilum is small gramnegative obligate intracellular bacterium, which is the main agent causing zoonotic diseases such as granulocytic anaplasmosis in humans (HGA) and animals (Nicholson et al., 2010; Hajdusek et al., 2013). A. phagocytophilum has a broad geographic distribution and a high degree of biological and clinical diversity. A. phagocytophilum was first recognized in Europe 80 years ago as a causative agent of tick-borne fever (TBF) in domestic ruminants. Ticks act as the main vector of $A$. phagocytophilum. A. phagocytophilum is mainly transmitted by ticks belonging to the Ixodes ricinus complex: Ixodes ricinus in Europe, Ixodes persulcatus in Eastern Europe and East Asia, and Ixodes scapularis and Ixodes pacificus in North America (Jaarsma et al., 2019). Infected ticks can transmit $A$. phagocytophilum to new hosts during the blood meal of its following stage. Ixodes ticks can be infected by $A$. phagocytophilum at each stage (except as eggs), but only nymphs and adult females can transmit this bacterium. Anaplasma bacteria infects a wide range of wild mammalian, domestic animals, rodents and humans. Two distinct $A$. phagocytophilum clades were detected based on four genes of bacteria genome: one clade contained A. phagocytophilum genotypes from questing I. ricinus and feeding I. ricinus from a broad array of hosts (humans, ungulates, birds and dogs), while the other clade comprised solely genotypes found in rodents and feeding I. trianguliceps (Blaňarová et al., 2014).

The role of wildlife species in the circulation of $A$. phagocytophilum is yet to be clearly determined, but several species of wild ruminants are thought to be important reservoirs. Several species of wild ruminant have been suggested to act as reservoir hosts, amongst them mainly the roe deer and the red deer (Woldehiwet 2010; Stuen et al., 2013; Dugat et al., 2015). In Lithuania, the cervids such as the roe deer, the red deer, and the moose are important game animals but their contribution as reservoirs for A. phagocytophilum remains unknown. Epide- miological studies in multiple countries have shown that the prevalence of $A$. phagocytophilum highly depends on the density of ticks and their potential hosts such as the cervids, which are one of the main sources of nutrition for $I x$ odes ticks. Previous studies have also suggested that A. phagocytophilum strains circulating in different ruminant species, possibly having distinct transmission cycles in nature, are independent of each other (Massung et al., 2002; Stuen et al., 2003, 2013).

The objectives of the study were to investigate the prevalence of $A$. phagocytophilum infections in the cervids and feeding ticks and to characterize the A. phagocytophilum strains obtained from the cervids and ticks based on sequence analysis of $m s p 4$ gene.

\section{MATERIALS AND METHODS}

Ticks were sampled from 44 cervids representing three species: the roe deer Capreolus capreolus, the red deer Cervus elaphus, and the moose Alces alces (Table 1) harvested by professional hunters during the hunting seasons of 2010-2013 and 2016-2017 in nine districts of Lithuania (Biržai, Jonava, Jurbarkas, Kaunas, Rumšiškès, Taurage, Ukmerge, Vievis, and Vilnius). Ticks were collected from hosts using tweezers and placed into $1.5 \mathrm{ml}$ tubes with $70 \%$ ethanol. Blood or spleen samples were collected from 29 animals (27 roe deer and two red deer) hunted from 2010 to 2013.

Identification of tick species and determination of the life stage was done microscopically based on morphological characters (Estrada-Peña et al., 2004). From partially or fully engorged ticks DNA was extracted using Genomic DNA Purification Kit (Thermo Fisher Scientific, Lithuania), while from unfed ticks DNA was extracted using a modified procedure with the ammonium hydroxide solution (2.5\%) (Stańczak et al., 1999). The lysates were stored at $-20^{\circ} \mathrm{C}$ until PCR analysis. The samples were screened for the presence of A. phagocytophilum by nested PCR as described by de la Fuente et al. (2005) and Bown et al. (2007): partial $m s p 4$ gene was amplified using primers 
MSP4AP5/MSP4AP3 for the first PCR reaction and $\mathrm{msp} 4 \mathrm{f} / \mathrm{msp} 4 \mathrm{r}$ for the second reaction. PCR was performed by using 2X PCR Master Mix (Thermo Fisher Scientific, Lithuania). Negative and positive controls were included in all runs. The nested PCR amplification products of the A. phagocytophilum msp4 gene were extracted from the agarose gel and purified using GeneJET Gel Extraction Kit (Thermo Fisher Scientific, Lithuania) following the manufacturer's instructions. The obtained sequences were analysed using MEGA X software and compared with the sequence data available from GenBank using the BLAST program. The phylogenetic tree was constructed using the Neighbor-joining method (NJ) with bootstrap analysis of 1000 replicates. The sequences obtained in our study received GenBank accession numbers MT886200-MT886214.

\section{RESULTS AND DISCUSSION}

The presence of $A$. phagocytophilum DNA in the analysed samples was confirmed by amplification of $381 \mathrm{bp}$ fragments of msp4 gene. A. phagocytophilum DNA was identified in ten (37.04\%) of the 27 roe deer. Neither of two examined red deer was infected with $A$. phagocy- tophilum. A total of 187 ticks of different developmental stages and sexes were collected from C. capreolus, C. elaphus, and A. alces (Table 1). Nine ticks were identified as Dermacentor reticulatus (four females and five males) and 178 as Ixodes ricinus ( 89 females, 87 males and two nymphs). For the detection of $A$. phagocytophilum, each tick was analysed individually. Based on nested PCR assay, A. phagocytophilum DNA was detected in 58.6\% (70/178) I. ricinus and $22.2 \%(2 / 9)$ D. reticulatus ticks. The bacterium was detected only in adult ticks. Both males and females of I. ricinus and $D$. reticulatus were infected with $A$. phagocytophilum (Table 1). The incidence of infection varied between different sexes of $I$. ricinus: females $(48.3 \%$; 43/89) were more frequently infected than males $(31.0 \% ; 27 / 87)$. Our findings showed that more frequently A. phagocytophilum-infected ticks were found on the roe deer and the moose (Table 1). From one moose 57 ticks of both species (52 I. ricinus and five D. reticulatus) were collected, of which $49.1 \%$ (28; 27 I. ricinus and one D. reticulatus) were infected with A. phagocytophilum. A total of 105 ticks (104 I. ricinus, and one D. reticulatus) were collected from 39 roe deer, and A. phagocytophilum infection was detected in

Table 1. Prevalence of Anaplasma phagocytophilum in ticks collected from the cervids in Lithuania

\begin{tabular}{|c|c|c|c|c|c|}
\hline \multirow{2}{*}{ Cervids species } & \multirow{2}{*}{ No. of cervids } & \multirow{2}{*}{ Tick stage } & \multicolumn{3}{|c|}{ Number of infected ticks/number of collected ticks (\%) } \\
\hline & & & Ixodes ricinus & Dermacentor reticulatus & Total: \\
\hline \multirow{4}{*}{$\begin{array}{l}\text { Roe deer } \\
\text { (Capreolus } \\
\text { capreolus) }\end{array}$} & \multirow{3}{*}{39} & Female & $37 / 69(53.6)$ & $0 / 1(0)$ & $37 / 70(52.9)$ \\
\hline & & Male & $5 / 33(15.2)$ & - & $5 / 33(15.2)$ \\
\hline & & Nymph & $0 / 2(0)$ & - & $0 / 2(0)$ \\
\hline & & Total: & $42 / 104(40.4)$ & $0 / 1(0)$ & $42 / 105(40.0)$ \\
\hline \multirow{4}{*}{$\begin{array}{c}\text { Moose (Alces } \\
\text { alces })\end{array}$} & \multirow{3}{*}{1} & Female & $5 / 8(62.5)$ & - & $5 / 8(62.5)$ \\
\hline & & Male & $22 / 44(50.0)$ & $1 / 5(20.0)$ & $23 / 49(46.9)$ \\
\hline & & Nymph & - & - & - \\
\hline & & Total: & $27 / 52(51.9)$ & $1 / 5(20.0)$ & $28 / 57(49.1)$ \\
\hline \multirow{4}{*}{$\begin{array}{c}\text { Red deer (Cer- } \\
\text { vus elaphus) }\end{array}$} & \multirow{3}{*}{4} & Female & $1 / 12(8.33)$ & $1 / 3(33.3)$ & $2 / 15(13.33)$ \\
\hline & & Male & $0 / 10$ & - & $0 / 10$ \\
\hline & & Nymph & - & - & - \\
\hline & & & $1 / 22(4.5)$ & $1 / 3(33.3)$ & $2 / 25(8.0)$ \\
\hline Total: & 44 & & $70 / 151(46.4)$ & $2 / 9(22.2)$ & $72 / 187(38.5)$ \\
\hline
\end{tabular}


40.0\% (42 I. ricinus ticks) (Table 1). From four red deer, 25 ticks (22 I. ricinus and 3 D. reticulatus) were collected, and A. phagocytophilum DNA was detected in two ticks (one I. ricinus and one D. reticulatus females) (Table 1).

In our previous studies conducted in Lithuania, the prevalence of $A$. phagocytophilum infection in questing $D$. reticulatus ticks reached 8\% (Paulauskas et al., 2012). However, A. phagocytophilum is found rarely (and at low prevalence) in questing $D$. reticulatus ticks. In eastern Poland, the prevalence of $A$. phagocytophilum in questing $D$. reticulatus varied from $0.7 \%$ to $2.0 \%$, depending on the tick collection area (Opalinska et al., 2016; Zajac et al., 2017). The results obtained in several studies suggest that this tick species is not a competent vector of $A$. phagocytophilum (Zygner et al., 2008). The ability of this tick species to transmit A. phagocytophilum has not been yet studied sufficiently. Furthermore, the presence of pathogens in ticks collected from the host does not provide information whether the source of infection is the blood of the host or whether the pathogen was present in the tick before feeding (Karbowiaka et al., 2014).

The prevalence of $A$. phagocytophilum in European I. ricinus tick populations varies. In Lithuania, the prevalence of $A$. phagocytophilum infection in questing I. ricinus ticks was found to be $2.9 \%$ (Paulauskas et al., 2012). In this study, the observed overall prevalence of $A$. phagocytophilum in I. ricinus feeding on the cervids was high (39.3\%). In a similar study conducted in Poland, in total, 238 partially or fully engorged female and 63 non-engorged male I. ricinus ticks were obtained from 51 cervids (20 fallow deer, 18 roe deer, and 13 red deer) (Michalik et al., 2009). The overall prevalence of $A$. phagocytophilum was higher in females $(22.7 \%)$ than in males (9.1\%) of I. ricinus (Michalik et al., 2009). It was noticed that female and male ticks from the PCR-positive cervids were more frequently infected than ticks from the PCR-negative hosts (Michalik et al., 2009). In a study performed in Germany, 331 engorged I. ricinus ticks from 44 roe deer individuals were screened, and $86.1 \%$ of them were infected with $A$. phagocytophi- lum (Overzier et al., 2013) with the higher infection rate detected in females $(99.0 \%)$ than in males $(64.8 \%)$. It was also noticed that engorged adult ticks removed from the roe deer were significantly more often positive for A. phagocytophilum than questing adult ticks (Overzier et al., 2013).

Wild ruminants are among the major feeding hosts for ticks in Europe. A great abundance of potential hosts is an important factor for tick expansion and potentially for the spread of anaplasmosis. There is evidence that higher cervid population densities may influence higher ticks densities, suggesting a positive effect on the prevalence of $A$. phagocytophilum. A study conducted in Norway demonstrated that the highest prevalence of $A$. phagocytophilum in I. ricinus occurred in locations with the highest densities of the roe deer and the red deer (Rosef et al., 2009). In Europe, A. phagocytophilum has been detected in local wild ruminant species with different prevalence (reviewed in Stuen et al., 2013). The roe deer show A. phagocytophilum prevalence rates reaching up to $98.9 \%$, and several genetic variants of A. phagocytophilum (both potentially pathogenic and non-pathogenic) have been found in the roe deer in Europe (Overzier et al., 2013). It has been suggested that the roe deer mainly acts as a reservoir of several $A$. phagocytophilum non-pathogenic variants for other animal species (Stuen et al., 2013). Other cervid species in Europe may also constitute efficient reservoir hosts of $A$. phagocytophilum as the pathogen has been detected in the red deer with up to $87 \%$ prevalence, in the fallow deer (Dama dama) with up to $72 \%$, in the sika deer (Cervus nippon) with up to $50 \%$, and in the moose with up to $42.9 \%$ (reviewed in Stuen et al., 2013; Pūraite et al., 2015; Ražanskè et al., 2019).

The sequence analysis of the msp4 gene among the 15 samples derived from the roe deer $(n=8)$ and I. ricinus $(n=6)$ and D. reticulatus $(n=1)$ ticks revealed ten different sequence types: five $m s p 4$ sequence types were detected in ticks and seven in roe deer. Two sequence variants ( 1 and 2) were detected in both $I$. ricinus ticks and roe deer (Table 2 ). 


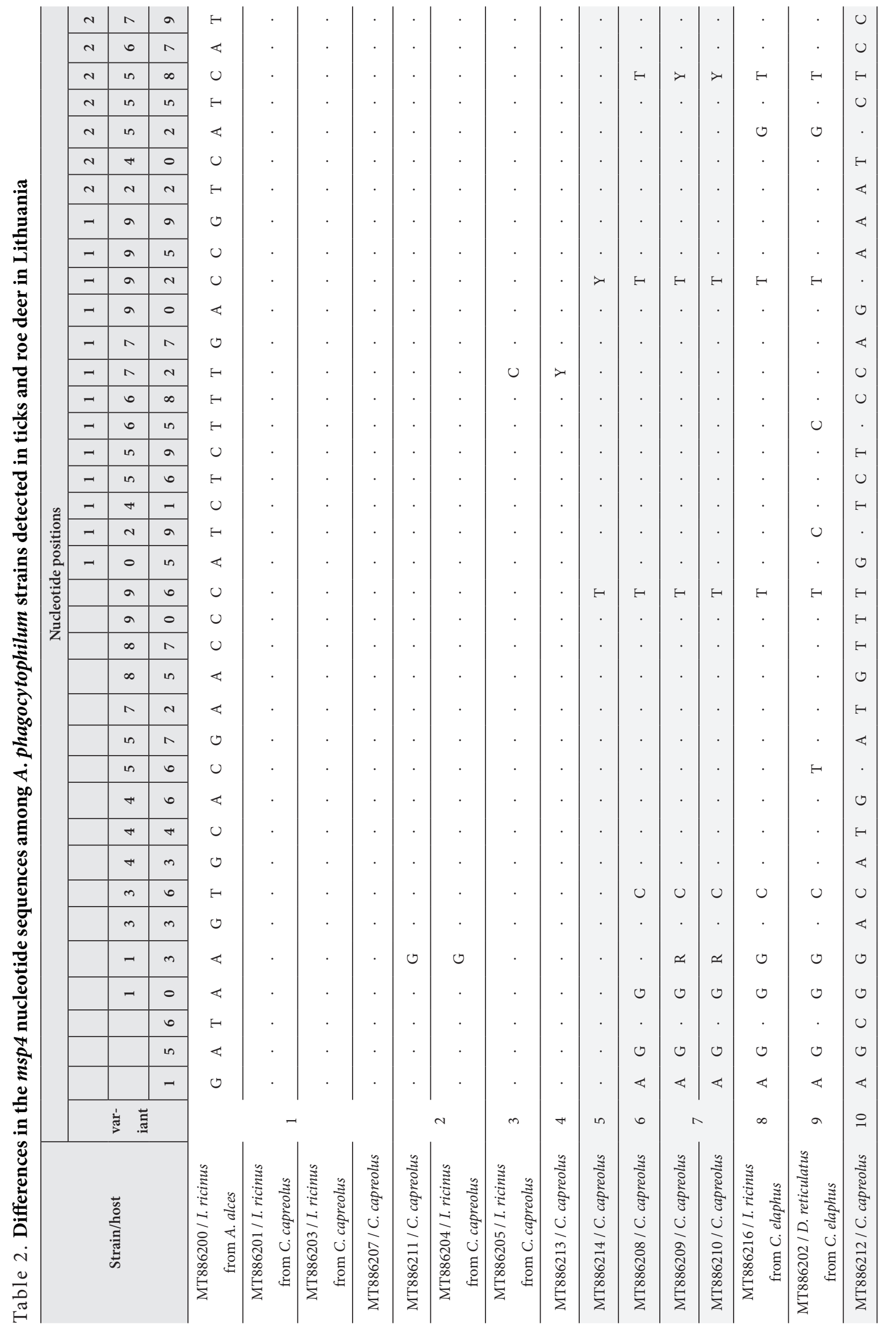


The analysed sequences showed $98-100 \%$ homology to each other (differing at one to $32 \mathrm{nu}-$ cleotide positions) and to the other $m s p 4$ gene sequences deposited in GenBank. Ambiguous nucleotides were observed in $m s p 4$ sequences of A. phagocytophilum derived from four roe deer (variants $4,5,7$ ). In all cases, ambiguous nucleotides were detected at positions where in other sequences either one of the two possible nucleotides were found, possibly indicating double infections (Table 2). Four A. phagocytophilum sequences (variant 1) derived from the roe deer (sample MT886207) and from $I$. ricinus ticks obtained from one moose (sample MT886200) and two roe deer individuals (samples MT886201 and MT886203) were $100 \%$ identical to each other and to other European sequences reported from I. rici- nus (Slovenia, KM205439) and D. reticulatus (Lithuania, JN181091) ticks and the roe deer from Germany (KU712165) and Slovenia (KM205437) (Figure). Four A. phagocytophilum $m s p 4$ sequence variants that were found in five roe deer (samples MT886214, MT886208, MT886209, MT886210, MT886212) had unique nucleotide composition (variants 5, 6 , $7,10)$ and therefore differed from other previously identified $A$. phagocytophilum sequences in the GenBank database (Table 2). A. phagocytophilum msp4 sequence derived from $D$. reticulatus tick (sample MT886202) collected from the red deer (variant 9) differed from other msp4 sequences detected in this study and was identical to the sequences derived from the roe deer in Slovakia (EU180060) and Hungary (MF974860) (Table 2, Figure).

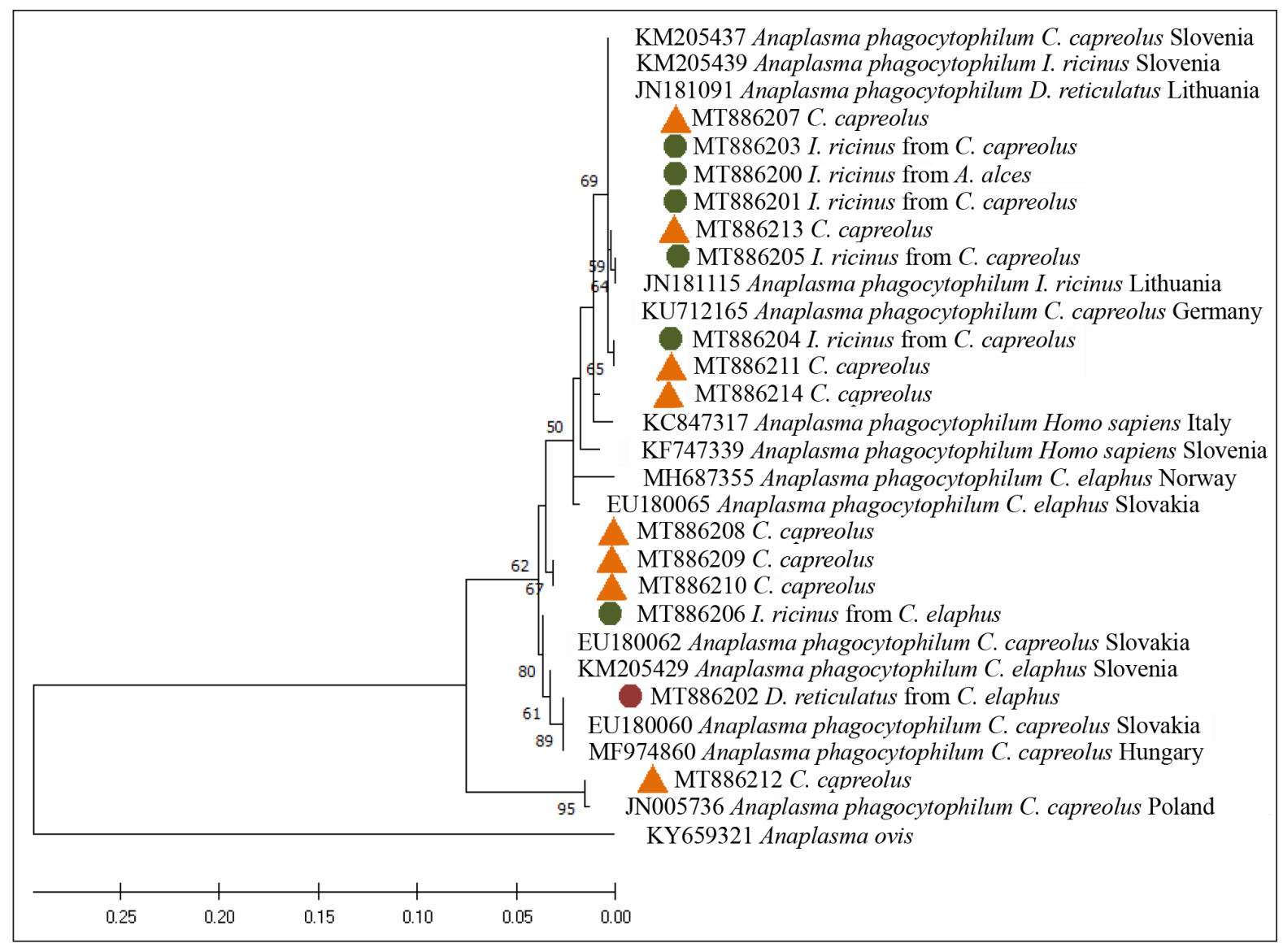

Figure. Phylogenetic tree of the msp4 gene sequences of A. phagocytophilum created using the NeighborJoining method and bootstrap analysis of 1000 replicates. Sequences with accession numbers were taken from GenBank for comparison. Samples sequenced in the present study are marked: $\triangle$ - A. phagocytophilum samples from roe deer; $\bigcirc$ - samples from $I$. ricinus ticks; $\bigcirc$ - sample from $D$. reticulatus tick 
One roe deer (sample MT886212) harboured A. phagocytophilum msp4 sequence (variant 10 ), which markedly differed from other sequences detected in ticks and roe deer in this study. The closely related $A$. phagocytophilum $m s p 4$ sequence (differed at one nucleotide position) was identified in the roe deer in Poland (Figure).

The majority of the A. phagocytophilum strains circulating in Europe are associated with the infection of the ruminants (Stuen et al., 2013). Previous studies demonstrated high sequence heterogeneity among $A$. phagocytophilum strains in $m s p 4$ gene isolated from different ruminant species. Bown et al. (2007) reported high variability of $A$. phagocytophilum msp4 sequences (11 variants) derived from 20 different hosts from several European countries and the USA. Six different A. phagocytophilum $m s p 4$ gene variants have been identified in the roe deer and six in the red deer in Norway (Ražanskè et al., 2019). In previous studies conducted in Lithuania, seven $m s p 4$ gene variants of A. phagocytophilum were detected in I. ricinus and Dermacentor reticulatus ticks (Paulauskas et al., 2012). Most of $A$. phagocytophilum strains detected in I. ricinus and D. reticulatus ticks collected in Lithuania are identical to the strains derived from various cervid species (Paulauskas et al., 2012).

\section{CONCLUSIONS}

Our results provide new information on the prevalence and distribution of $A$. phagocytophilum strains in the roe deer and I. ricinus and $D$. reticulatus ticks collected from the roe deer, the red deer, and the moose in Lithuania. The results of the present study demonstrate high infection rates of $A$. phagocytophilum in ticks parasitizing different cervid species and the possible risk of transmitting these infections to their hosts. Five $m s p 4$ gene variants of A. phagocytophilum were detected in ticks and seven in red deer. Ten A. phagocytophilum msp4 sequences derived from ticks and the roe deer in this study had been previously described in ticks, the roe deer, the red deer, and the moose in other European countries, while five sequences derived from the roe deer differed from other previously identified A. phagocytophilum msp4 gene sequences in the GenBank database.

Received 14 July 2020 Accepted 18 August 2020

\section{References}

1. Blaňarová L, Stanko M, Carpi G, Miklisováv D, Víchová B, Mošanský L, et al. Distinct Anaplasma phagocytophilum genotypes associated with Ixodes trianguliceps ticks and rodents in central Europe. Ticks Tick Borne Dis. 2014; 5(6): 928-38.

2. Bown KJ, Lambin X, Ogden NH, Petrovec M, Shaw SE, Woldehiwet Z, Birtles RJ. Highresolution genetic fingerprinting of European strains of Anaplasma phagocytophilum by use of multilocus variable-number tandem-repeat analysis. J Clin Microbiol. 2007; 45(6): 1771-6.

3. de la Fuente J, Massung RF, Wong SJ, Chu FK, Lutz H, Meli M, Loewenich FD, Grzeszczuk A, Torina A, Caracappa S, Mangold AJ, Naranjo V, Stuen S, Kocan KM. Sequence analysis of the msp4 gene of Anaplasma phagocytophilum strain. J Clin Microbiol. 2005; 43(3): 1309-17.

4. Dugat T, Lagrée AC, Maillard R, Boulouis HJ, Haddad N. Opening the black box of Anaplasma phagocytophilum diversity: current situation and future perspectives. Front Cell Infect Microbiol. 2015; 61: 1-18.

5. Estrada-Peña A, Bouattour A, Camicas JL, Walker AR. Ticks of domestic animals in the Mediterranean region: a guide to identification of species. Zaragoza: University of Zaragoza; 2004.

6. Hajdusek O, Śíma R, Ayllón N, Jalovecká M, Perner J, de la Fuente J, Kopáček P. Interaction of the tick immune system with transmitted pathogens. Front Cell Infect Microbiol. 2013; 3: $26: 1-15$. 
7. Jaarsma RI, Sprong H, Takumi K, Kazimirova M, Silaghi C, Mysterud A, Rudolf I, Beck R, Földvari G, Tomassone L, Groenevelt M, Everts RR, Rijks JM, Ecke F, Hörnfeldt B, Modry D, Majerova K, Votypka J, Estrada-Pena A. Anaplasma phagocytophilum evolves in geographical and biotic niches of vertebrates and ticks. Parasites Vectors. 2019; 12: 328.

8. Karbowiaka G, Vichová B, Slivinskac K, Werszk J, Didykc J, Pet'ko B, Stanko M, Akimov I. The infection of questing Dermacentor reticulatus ticks with Babesia canis and Anaplasma phagocytophilum in the Chernobyl exclusion zone. Vet Parasitol. 2014; 204(3-4): $372-5$.

9. Massung RF, Mauel MJ, Owens JH, Allan N, Courtney JW, Stafford KC, Mather TN. Genetic variants of Ehrlichia phagocytophila Rhode Island and Connecticut. Emerg. Infect. Dis. 2002; 8(5): 467-72.

10. Michalik J, Stanczak J, Racewicz M, Cieniuch S, Sikora B, Szubert-Kruszynska A, Grochowalska R. Molecular evidence of Anaplasma phagocytophilum infection in wild cervids and feeding Ixodes ricinus ticks from westcentral Poland. Clin Microbiol Infect Dis. 2009; 15 Suppl 2: 81-3.

11. Nicholson WL, Allen KE, McQuiston JH, Breitschwerdt EB, Little SE. The increasing recognition of rickettsial pathogens in dogs and people. Trends Parasitol 2010; 26(4): 205-12.

12. Opalinska P, Wierzbicka A, Asman M. The PCR and nested PCR detection of Borrelia burgdorferi sensu lato, Anaplasma phagocytophilum and Babesia microti in Dermacentor reticulatus F. collected in a new location in Poland (Trzciel, Western Poland). Acta Parasitol. 2016; 61(4): 849-54.

13. Overzier E, Pfister K, Herbb I, Mahling M, Böck G, Silaghi C. Detection of tick-borne pathogens in roe deer (Capreolus capreolus), in questing ticks (Ixodes ricinus), and in ticks infesting roe deer in southern Germany. Ticks Tick Borne Dis. 2013; 4(4): 320-328.
14. Paulauskas A, Radzijevskaja J, Rosef O. Molecular detection and characterization of Anaplasma phagocytophilum strains. Comp Immunol Microbiol Infect Dis. 2012; 35(2): 187-95.

15. Pūraitė I, Rosef O, Paulauskas A, Radzijevskaja J. Anaplasma phagocytophilum infection in moose (Alces alces) in Norway. Microbes Infect. 2015; 17(11-12): 823-8.

16. Radzijevskaja J, Paulauskas A, Rosef O. Prevalence of Anaplasma phagocytophilum and Babesia divergens in Ixodes ricinus ticks from Lithuania and Norway. Int J Med Microbiol. 2008; 298: 218-21.

17. Ražanskè I, Rosef O, Radzijevskaja J, Bratchikov M, Griciuvienè L, Paulauskas A. Prevalence and co-infection with tick-borne Anaplasma phagocytophilum and Babesiab spp. in red deer (Cervus elaphus) and roe deer (Capreolus capreolus) in Southern Norway. Int J Parasitol Parasites Wildl. 2019; 8: 127-34.

18. Rosef O, Paulauskas A, Radzijevskaja J. Prevalence of Borrelia burgdorferi sensu lato and Anaplasma phagocytophilum in questing $I x$ odes ricinus ticks in relation to the density of wild cervids. Acta Vet Scand. 2009; 51(1): 47.

19. Stańczak J, Racewicz M, Kubica-Biernat B, Kruminis-Łozowska W, Dąbrowski J, Adamczyk A, Markowska M. Prevalence of Borrelia burgdorferi sensu lato in Ixodes ricinus ticks (Acari, Ixodidae) in different Polish woodlands. Ann Agric Environ Med. 1999; 6(2): 127-32.

20. Stuen S, Bergstroøm K, Petrovec M, van de Pol I, Schouls LM. Differences in clinical manifestations and hematological and serological responses after experimental infection with genetic variants of Anaplasma phagocytophilum in sheep. Clin Diagn Lab Immunol. 2003; 10(4): 692-5.

21. Stuen S, Granquist EG, Silaghi C. Anaplasma phagocytophilum - a widespread multi-host pathogen with highly adaptive strategies. Front Cell Infect Microbiol. 2013; 3: 31. 
22. Teodorowski O, Radzki R, Kalinowski M, Winiarczyk S, Garcia Bocanegra I, Winiarczyk D, Adaszek L. Molecular detection of Anaplasma phagocytophilum in roe deer (Capreolus capreolus) in eastern Poland. Ann Argic Environ Med. 2020: 1-4.

23. Woldehiwet Z. The natural history of Anaplasma phagocytophilum Vet Parasitol. 2010; 167(2-4): 108-22.

24. Zajac V, Wójcik-Fatla A, Sawczyn A, Cisak E, Sroka J, Kloc A, Zając Z, Buczek A, Dutkiewicz J, Bartosik K. Prevalence of infections and co-infections with 6 pathogens in Dermacentor reticulatus ticks collected in eastern Poland. Ann Argic Environ Med. 2017; 24(1): 26-32.

25. Zygner W, Jaros S, Wedrychowicz H. Prevalence of Babesia canis, Borrelia afzelii, and Anaplasma phagocytophilum infection in hard ticks removed from dogs in Warsaw (central Poland). Vet Parasitol. 2008; 153(1-2): 139-42.
Jana Radzijevskaja, Justina Snegiriovaitè, Artūras Kibiša, Irma Ražanskè,

Algimantas Paulauskas

\section{ANAPLASMA PHAGOCYTOPHILUM IN- FEKCIJOS, NUSTATYTOS LIETUVOJE ELNINIAMS GYVŪNAMS IR JUOS PARA- ZITUOJANČIOMS ERKE்MS, MOLEKULINE் CHARAKTERISTIKA}

Santrauka

Anaplasma phagocytophilum bakterija yra pagrindinis zoonotinès ligos - anaplazmozès - sukèlèjas. Pagrindiniai A. phagocytophilum pernešèjai yra Ixodes ricinus kompleksui priklausančios erkès. A. phagocytophilum turi platų geografini pasiskirstymą ir didelę biologinę bei klinikinę ìvairovę. Ivairiose šalyse atlikti epidemiologiniai tyrimai rodo, kad A. phagocytophilum paplitimas labai priklauso nuo erkių tankumo ir jų potencialių šeimininkų, tokių kaip elniniai gyvūnai, kurie yra vieni iš pagrindinių Ixodes genties erkių maitinimosi šaltinių. Lietuvoje elniniai gyvūnai yra svarbūs medžiojamieji gyvūnai, tačiau jų kaip A. phagocytophilum rezervuarų vaidmuo lieka nežinomas. Tyrimo tikslai buvo ištirti elninių gyvūnų ir juos parazituojančių erkių užsikrètimą $A$. phagocytophilum bei apibūdinti A. phagocytophilum padermes, išskirtas iš elninių gyvūnų ir erkių, remiantis msp4 geno sekų analize. Erkès buvo surinktos nuo 44 elninių gyvūnų (stirnų, tauriujų elnių ir briedžių), sugautų 2010-2013 ir 2016-2017 m. medžioklès sezono metu. Iš viso nuo gyvūnų buvo surinktos 187 erkès. Buvo paimti 29 gyvūnų (27 stirnų ir 2 tauriųjų elnių) kraujo ir blužnies mėginiai. A. phagocytophilium DNR buvo nustatyta $10(37,04 \%)$ iš 27 stirnų. Bendras I. ricinus ir D. reticulatus erkių užsikrètimas $A$. phagocytophilum atitinkamai buvo 39,3\% (70/178) ir 22,2 \% (2/9). A. phagocytophilum msp4 geno sekų analizè atskleidè devynis skirtingus sekų variantus: erkèse buvo aptikti penki msp4 sekų variantai, o stirnose - septyni.

Raktažodžiai: Anaplasma phagocytophilum, erkès, Ixodes ricinus, Dermacentor reticulatus, elniniai gyvūnai 